\title{
Microbial resistance and frequency of extended-spectrum beta-lactamase (ESBL) in isolated from blood cultures
}

\author{
Resistência microbiana e frequência de betalactamase de espectro estendido \\ (ESBL) em isolados de hemoculturas
}

Ruan Carlos Gomes da Silva ${ }^{1}$; Amanda Cristina de Oliveira Silva ${ }^{1}$; Sibele Ribeiro de Oliveira ${ }^{2}$

\begin{abstract}
Introduction: The emergence and spread of isolated carriers of extended-spectrum beta-lactamase (ESBL) have complicated the treatment of nosocomial infections, since its production is not easily identified by the sensitivity tests, routinely performed in clinical laboratories, leading to difficulties in the hospital control of resistant microorganisms and antibiotics misuse. Objective: The objective of this study was to analyze the resistance profile and the frequency of ESBL in Gram-negative bacteria isolated from blood cultures. A hundred bacterial samples from blood cultures of adult patients were analyzed, which were phenotypically identified by biochemical tests of carbohydrates fermentation and submitted to determination of the resistance profile by disc diffusion test and ESBL screening by disc approximation and disc replacement methods. Results: Among the bacterial samples tested, 30 were identified as Gram-negative bacteria, predominantly by Proteus mirabilis, Pantoea agglomerans, and Escherichia coli. Of these, 73.33\% were positive for the detection of ESBL by phenotypic tests, and was found mainly in Pantoea agglomerans, Proteus mirabilis, and Enterobacter cloacae. Conclusion: The increase in the occurrence of ESBL in different Enterobacteriaceae shows the importance of the amplification of detection in other species than Escherichia coli or Klebsiella sp., so that the assistance to the patient is not restrained, since these resistant bacteria cannot be detected by the laboratories. Considering the frequency of ESBL in this study, we highlight the importance of its detection, aiming to its contribution to the development of improvements in the health care policies of hospitals.
\end{abstract}

Key words: bacterial resistance; extended-spectrum beta-lactamase; ESBL; hospital infection.

\section{INTRODUCTION}

Nosocomial infections are a significant public health problem, because the effect of an unsuccessful treatment create situations that increase the time of hospitalization and the expenditure on medicines, generating recurrence, which are caused, among others, by the production of enzymes responsible for degrading the main antimicrobial used in clinical practice ${ }^{(14)}$

One of the main mechanisms of bacterial resistance is the production of extended-spectrum beta-lactamases (ESBL), enzyme mediated by non-inducible plasmid gene, capable of hydrolyzing the oxyimino-beta-lactams chain present in the chemical structure of beta-lactams, inactivating them and providing greater bacterial resistance, which extends its spectrum of activity to the broad-spectrum antimicrobials ${ }^{(11,21)}$.

ESBLs provide resistance to penicillins, all cephalosporins, and monobactams (including, aztreonam), but do not provide resistance to cephamycins (cefoxitin and cefotetan) and carbapenems (imipenem, meropenem, and ertapenem) ${ }^{(10)}$, however, they are inhibited by beta-lactamases inhibitors, such as clavulanic acid, sulbactam and tazobactam ${ }^{(18)}$.

ESBLs are derived from genetic mutations (temoneira [TEM] and sulfidril variable [SHV]), and are found mainly in Escherichia coli and Klebsiella sp., but can also be detected in Proteus mirabilis, Enterobacter sp., Acinetobacter sp.,

First submission on 04/11/14; last submission on 28/11/14; accepted for publication on 08/12/14; published on 20/12/14

1. Biomedical science at Caruaruense Association for Higher and Technical Education (Associação Caruaruense de Ensino Superior e Técnico [ASCES]), Caruaru-PE.

2. PhD in Biological Sciences by Pernambuco Federal University (UFPE); teaching at ASCES, Caruaru-PE. 
Pseudomonas sp., and other Enterobacteriaceae species ${ }^{(8)}$. Currently, a major expansion of CTX-M type ESBL, whose preferred substrate is cefotaxime ${ }^{(16)}$, made this type in the most widely distributed, exceeding the incidence of SHV and TEM ${ }^{(6)}$.

In samples of Gram-negative bacilli isolated from blood cultures, there is an association between the emergence and spread of patients isolated with ESBL and multiple antibiotic resistance, particularly the $3^{\text {rd }}$ and $4^{\text {th }}$-generation cephalosporins ${ }^{(19)}$, resulting in fewer treatment options, increased risk of failures in the treatment of patients infected with these strains, as well as morbiditymortality ${ }^{(9)}$.

ESBL production is not easily recognized by in vitro antimicrobial susceptibility testing, routinely performed in a clinical laboratory, confirmatory tests are needed to detect the phenotype and, in some cases, the resistance genotype ${ }^{(13)}$. These limitations in ESBL detection have hampered the hospital control of resistant microorganisms and favored the increase in prescription and overuse of antibiotics ${ }^{(21)}$. Furthermore, the involvement of ESBL-producing bacteria in the blood of hospitalized patients is directly related to complications in pathological conditions, worsens septicemia ${ }^{(17)}$.

Clinical and Laboratory Standards Institute (CLSI) recommends that screening and confirmatory assays are routinely performed to Klebsiella pneumoniae, Klebsiella oxytoca, and Escherichia coli, are considered the classic production of the enzyme, besides Proteus mirabilis ${ }^{(3)}$. However, other standardization can be used in phenotypic research on ESBL in isolates that are not covered by CLSI, including the British Society for Antimicrobial Chemotherapy Methodology (BSCA) ${ }^{(8)}$.

In view of the possibility of ESBL positive bacteremia and the importance of this hospital notification, the present study aimed to analyze the antimicrobial susceptibility profile of Gram-negative bacteria from positive blood cultures, as well as the frequency of ESBL-producing strains of patients of a hospital at Agreste Pernambucano, located in the city of Caruaru-PE.

\section{MATERIAL AND METHODS}

\section{Location of study and population}

In the period between February and June 2014, 100 samples from blood cultures of hospitalized patients were analyzed in a hospital at Agreste Pernambucano, located in the city of Caruaru-PE.
This study was approved by the Research Ethics Committee of the Caruaruense Association of Higher Education (Associação Caruaruense de Ensino Superior [ASCES]) under the number 421338.

\section{Samples collection and processing}

From the blood culture bottles provided by the Hospital Regional do Agreste (HRA), aliquots were aspirated for preparing a slide, which was stained by the Gram method, and for sowing in the medium Sheep Blood agar and MacConkey agar. Based on the colonies obtained, the phenotypic identification of the genus was carried out and, where possible, also the species, according to the macroscopic and microscopic characteristics of the colonies and with the results of biochemical tests of carbohydrates fermentation in Triple Sugar Iron agar (TSI), Sulphide Indole Motility (SIM), Simmons Citrate agar, Christensen Urea agar, and Instituto Adolfo Lutz medium (IAL).

\section{Determination of sensitivity pattern}

The identified strains were submitted to disc diffusion test, using broad-spectrum beta-lactam proposed by CLSI 2014. To test performing, the suspension of the bacteria in test, adjusted to McFarland 0.5 scale standard, was inoculated on the surface of a Müeller-Hinton agar plate. Subsequently, the ceftriaxone, cefotaxime, ceftazidime, cefepime and aztreonam discs were placed. The strains were evaluated for resistance according to CLSI 2014 guidelines, regarding their inhibition zones sizes ${ }^{(2)}$.

\section{Phenotypic detection of ESBL-producing strains}

ESBL enzyme research was performed by two phenotypic tests:

1) disc approximation - a plate of Müeller-Hinton agar was used, previously inoculated with the strain to be studied and adjusted to McFarland 0.5 scale. One amoxicillin/clavulanic acid disc $(20 \mu \mathrm{g} / 10 \mu \mathrm{g})$ was placed in the center of the plate and around it the antimicrobial markers: cefotaxime/ceftriaxone $(30 \mu \mathrm{g})$, ceftazidime $(30 \mu \mathrm{g})$, cefepime $(30 \mu \mathrm{g})$, and aztreonam $(30 \mu \mathrm{g})$, at a distance of $20 \mathrm{~mm}$, center to center in relation to the central disc. After incubation for $18-24$ hours at $35-37^{\circ} \mathrm{C}$, the test interpretation was performed. The increase of the inhibition zone diameter or appearance of an empty area (distortion of the zone around the betalactam disc) indicated the presence of a ESBL-producing sample ${ }^{(8)}$;

2) disc replacement - consisted of placing two amoxicillin/ clavulanic acid discs $(20 \mu \mathrm{g} / 10 \mu \mathrm{g})$ on the surface of Müeller- 
Hinton agar plate, and incubated for 1 hour at $35-37^{\circ} \mathrm{C}$ in a bacteriological incubator, for diffusion of clavulanic acid in agar medium. Subsequently, the discs were removed with sterile forceps and, in the same location, were placed Ceftazidime $(30 \mu \mathrm{g})$ and Cefotaxime $(30 \mu \mathrm{g})$ discs. After appropriate incubation, the zones containing clavulanic acid were measured and compared with those of the discs containing only cephalosporin. In the presence of an $\geq 5 \mathrm{~mm}$ increase in the disc combined with the inhibitor, in relation to the disc without clavulanate, the strain was considered positive for ESBL ${ }^{(12)}$.

\section{RESULIS}

Among the 100 samples obtained from blood cultures, in 30 Gram negative bacteria were identified and therefore, selected for the study. According to the interpretation of biochemical tests, bacterial samples were classified into five distinct species, with the predominance of Proteus mirabilis (23.33\%), Pantoea agglomerans (20\%), Escherichia coli (16.66\%), and Enterobacter cloacae (10\%), and a variety of other bacterial species, such as Proteus penneri (6.66\%), Acinetobacter sp. (6.66\%), Enterobacter gergoviae (6.66\%), Enterobacter sakazakii (6.66\%), and Pseudomonas sp. (3.33\%) (Figure 1).

From the identification of the strains, the disc diffusion test was performed, and we observed that cephalosporins and monobactam showed the following resistance rates: ceftriaxone (80\%), ceftazidime $(56.66 \%)$, cefotaxime $(86.66 \%)$, cefepime $(60 \%)$, and aztreonam (60\%) (Figure 2). Figure 2 shows the high resistance rates and low rates sensitivity of the isolates for the broad spectrum beta-lactam, widely used in clinical practice.

Regarding ESBL research, among the 30 bacterial strains, $73.33 \%$ (22) were positive by phenotypic tests, among them, 27.27\% (six) Pantoea agglomerans, 18.18\% (four) Proteus mirabilis, 13.63\% (three) Enterobacter cloacae, 9.09\% (two) Proteus penneri, Enterobacter gergoviae and Acinetobacter sp. and 4.54\% (one) Escherichia coli, Pseudomonas sp. and Enterobacter sakazakii (Figure 3).

Whereas a strain is ESBL-producing when the test is positive for one or more of the employed substrates, it was found that the 22 samples tested were positive for the enzyme by phenotypic tests. The disc approximation method confirmed the presence of ESBL in 22 strains, all detected by cefotaxime/ceftriaxone, and $20(66.66 \%)$ also positive for ceftazidime, aztreonam, and

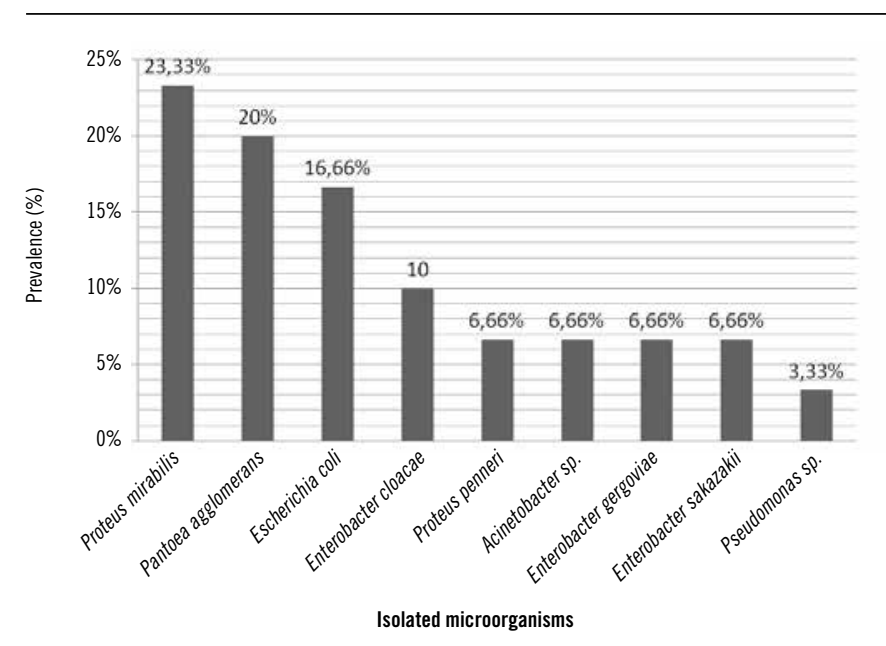

FIGURE 1 - Frequency of microorganisms isolated from analyzed blood cultures

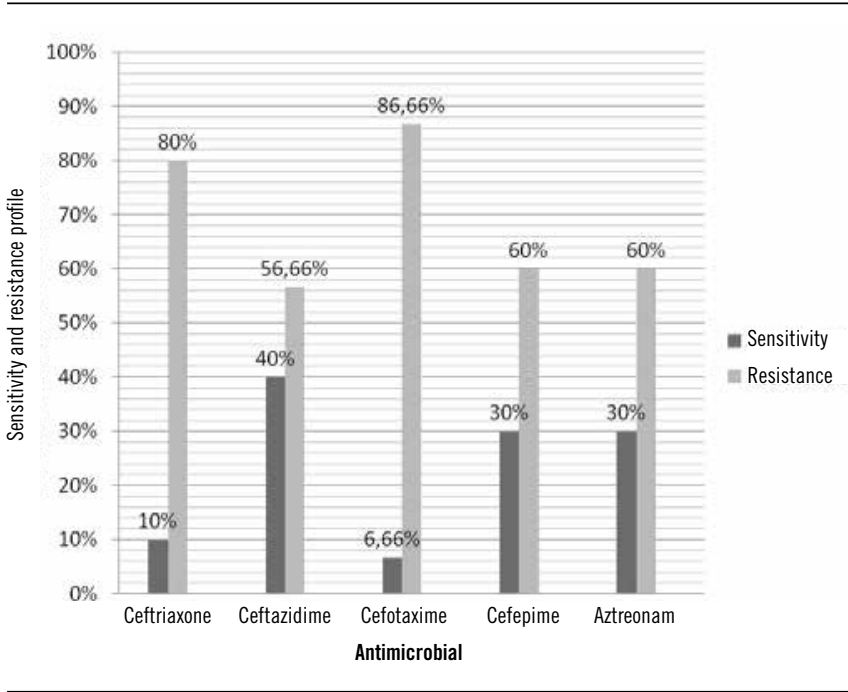

FIGURE 2 - Sensitivity and resistance profile of Gram-negative strains to beta-lactams

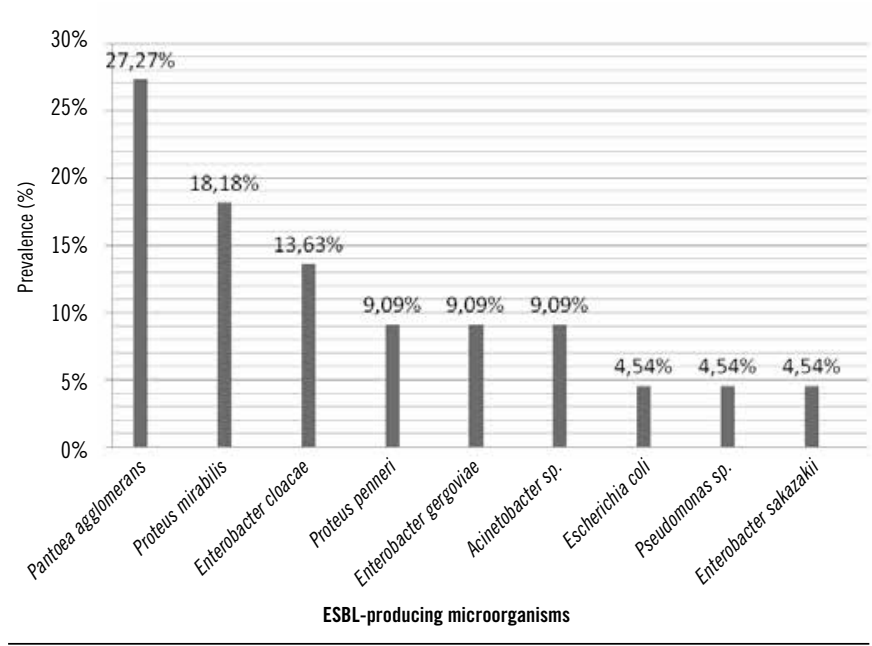

FIGURE 3 - Phenotypic prevalence of ESBL-producing strains

ESBL: Extended-spectrum beta-lactamases. 
cefepime. The disc replacement test confirmed the presence of ESBL in 18 strains (60\%), all positive for cefotaxime, and $16(53.33 \%)$ were also positive with the ceftazidime substrate. Four samples corresponding to Pantoea agglomerans (one), Acinetobacter sp. (two), and Pseudomonas sp. (one) were positive to ESBL only for the disc approximation test, with all employed substrates (Table).

Evaluating the positive blood cultures by the presence of ESBL, we find that most of these cases occurred in female patients, with a prevalence of $59.10 \%(n=13)$, while in males the prevalence was $40.90 \%(n=9)$. Correlating the presence of ESBL with the place inside the hospital where the presence of bacteria was detected, from the blood cultures collected, it was noted that this enzyme was present most often in the Intensive Care Unit (ICU), showing prevalence of $73 \%(n=16)$, when compared with its frequency in wards $27 \%(n=6)$ (Figure 4)

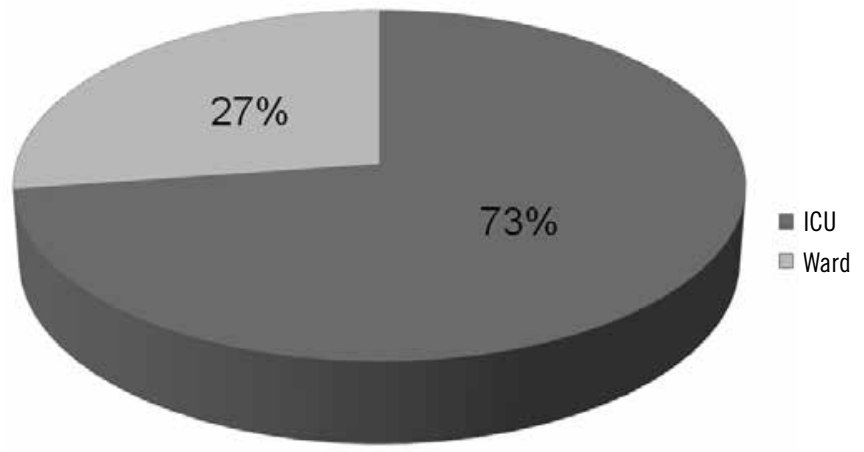

FIGURE 4 - Relationship between positive blood culture due to the presence of ESBL and the location of patient inside the hospital

ESBL: Extended-spectrum beta-lactamases; ICU: Intensive Care Unit.

\section{DISCUSSION}

Infections caused by ESBL-producing microorganisms have become a concern for the development of antimicrobial therapy, since these infections have major impact on the morbidity and mortality rates, and in hospital costs. This fact is due to the fact that the clinical implications of ESBL are serious, and it is essential to understand this mechanism resistance using sensitive and specific diagnostic techniques, in such a way as to properly conduct the treatment, monitor antimicrobial resistance, and implement intervention strategies ${ }^{(20)}$.

In the present study, we observed a diversification of the isolated bacterial genus, with predominance of Proteus mirabilis (23.33\%) and Pantoea agglomerans (20\%). Gram-negative bacilli are among the main bacterial strains responsible for nosocomial infections, thus, it is important to study them in this environment, especially as regards the development of resistance mechanisms ${ }^{(10)}$. In contrast to these results, Alves et al. (2012) analyzed 170 blood cultures of patients admitted to the ICU, from a hospital in São José dos Campos-SP, from January to July 2011, and found the following bacterial genus: Pseudomonas aeruginosa (12.2\%), Klebsiella pneumoniae (8.1\%), Acinetobacter baumanii (3.3\%), Enterobacter cloacae (0.8\%), Escherichia coli (0.8\%), and Proteus mirabilis $(0.8 \%)^{(1)}$.

Dantas (2011) also found very low prevalence of Proteus mirabilis (1.85\%) in nosocomial bacteremia, from May 2009 to February $2010^{(4)}$. This fact emphasizes the importance of this study results with respect to the current prevalence in the studied region, since this pathogen has significant potential for involvement in severe infections.

The susceptibility pattern of isolated strains for the betalactams showed high percentage of resistance, which can be linked

TABLE - ESBL detection results in positive strains for enzyme using the disc approximation and disc replacement methods

\begin{tabular}{|c|c|c|c|c|c|}
\hline Bacteria & $n(\%)$ & DA CTX/CR0 (\%) & DA CAZ/CPM/ATM (\%) & DR CTX & DR CAZ \\
\hline Pantoea agglomerans & $6(27.27 \%)$ & $6(27.27 \%)$ & $6(27.27 \%)$ & $5(27.77 \%)$ & $5(27.77 \%)$ \\
\hline Proteus mirabilis & $4(18.18 \%)$ & $4(18.18 \%)$ & $3(13.63 \%)$ & $4(18.18 \%)$ & $3(13.63 \%)$ \\
\hline Proteus penneri & $2(9.09 \%)$ & $2(9.09 \%)$ & $2(9.09 \%)$ & $2(9.09 \%)$ & $2(9.09 \%)$ \\
\hline Enterobacter gergoviae & $2(9.09 \%)$ & $2(9.09 \%)$ & $2(9.09 \%)$ & $2(9.09 \%)$ & $2(9.09 \%)$ \\
\hline Escherichia coli & $1(4.54 \%)$ & $1(4.54 \%)$ & $1(4.54 \%)$ & $1(4.54 \%)$ & $1(4.54 \%)$ \\
\hline Pseudomonas sp. & $1(4.54 \%)$ & $1(4.54 \%)$ & $1(4.54 \%)$ & - & - \\
\hline Enterobacter sakazakii & $1(4.54 \%)$ & $1(4.54 \%)$ & $1(4.54 \%)$ & $1(4.54 \%)$ & $1(4.54 \%)$ \\
\hline
\end{tabular}

ESBL: extended-spectrum beta-lactamases; DA: disc approximation; CTX: cefotaxime; CRO: ceftriaxone; CAZ: ceftazidime; CPM: cefepime; ATM: aztreonam; DR: disc replacement. 
to the overuse of third and fourth generation cephalosporins, as well as difficulty in hospital controlling resistant microorganisms, bringing consequences such as unsuccessful treatments and unfavorable clinical outcomes.

Cabral (2011), analyzing the microorganisms resistance to beta-lactam antibiotics, reveal the true problems for the treatment of multiresistant isolates and established an association between the resistance profile and genes for beta-lactamases, since isolates of the same resistance pattern had the same genetic content, and thus, they were able to hydrolyze fourth generation cephalosporins and aztreonam ${ }^{(2)}$.

The Clinical Microbiology Laboratory plays a key role in the detection of ESBL-producing Enterobacteriaceae, contributing to the orientation of a therapeutic approach and the application of preventive measures to control these nosocomial agents and isolation of patients, in order to minimize the spread of these pathogens $^{(7,12,13)}$.

In this study, the production of ESBL showed a frequency of $73.33 \%$, and was mainly detected in Pantoea agglomerans (27.27\%), Proteus mirabilis (18.18\%), and Enterobacter cloacae (13.63\%), showing the dissemination of this resistance mechanism in the Enterobacteriaceae family. Phenotypic confirmatory methods are routinely performed for ESBL detection in Escherichia coli and Klebsiella sp., according to the CLSI, which recommends its screening only in these isolated, since they are considered the main producers. However, it is noteworthy that the increase on ESBL occurrence in other Enterobacteriaceae reveals the importance of extending this detection in other species than Escherichia coli and Klebsiella sp. ${ }^{(10)}$.

Lago et al. (2010) reported that $49.6 \%$ of their isolated ESBLproducing were Enterobacter sp., showing that, since the pathogen is identified as Enterobacter sp., it is 8.43 times more likely to be ESBL-producing ${ }^{(10)}$. In Japan, a study carried out by Datta et al. (2014) showed that in a number of 60 Enterobacteriaceae strains, 60\% $(n=36)$ were identified as Proteus mirabilis and considered ESBL-producing, drawing attention to the fact these bacteria may not be detected by most clinical laboratories, suppressing some managements of assistance to the patient ${ }^{(5)}$.

The sensitivity of phenotypic methods was satisfactory, of low cost, and thus feasible for use in the ESBL screening. However, we found that the disc replacement test was unable to detect the ESBL in four isolated, perhaps this was due to the fact that a smaller range of substrates was employed in the test, when compared to the disk approximation method. According to Karoline et al. (2008) and Wiegand et al. (2007), the disc approximation method uses many antibiotics, so that it presents a sensitivity of $94.1 \%$ and specificity of $81.4 \%{ }^{(8,22)}$. Martins et al. (2011) found in their study 91.6\% of sensitivity for the disc replacement test ${ }^{(12)}$.

Regarding the distribution of hospital infections by the ESBL-producing bacteria, it was observed that $73 \%$ of patients were admitted to the ICU, and, thus, showing higher risks of infections by these microorganisms, since, in this environment are performed: invasive procedures, prolonged hospitalization, and use of broad-spectrum antibiotics ${ }^{(15)}$.

One limitation of this study was not using of the combined disc method recommended by the CLSI for phenotypic research on ESBL, due to the difficulty in obtaining the discs in the studied location. However, it is demonstrated the possibility of using alternative techniques in the study of this bacterial resistance mechanism.

\section{CONCLUSION}

ESBL frequency was high, prevailing Enterobacter genus as potential producer, demonstrating that the production of this enzyme in Enterobacteriaceae not belonging to the Klebsiella genus is no longer an exception. This reinforces the need for knowledge and use of techniques in its research. This high positivity rate may occur due to the selective pressure resulting in the indiscriminate use of broad-spectrum cephalosporins.

The techniques proposed in this paper proved to be useful for ESBL screening, with satisfactory sensitivity and low cost, and able to confirm this important resistance mechanism that hinders the beta-lactam antibiotics therapy used in clinical. We also observed the importance of testing a wider variety of substrates, thus increasing test sensitivity.

With the spread of bacterial strains in hospitals worldwide, it is necessary to know the prevalence of ESBL production, in an attempt to contribute to the formulation of a policy of therapy in high-risk units, where infection rates by multidrug resistant microorganisms are high. In addition, the knowledge of resistance standard in a geographical area, guide the proper and discerning use of antimicrobials.

\section{ACKNOWLEDGEMENTS,}

To the Microbiology Laboratory of the Hospital Regional do Agreste, for the supply of blood cultures that were analyzed, and to the Asces School, for the financial support. 


\section{RESUMO}

Introdução: A emergência e a disseminação dos isolados portadores de betalactamase de espectro estendido (ESBL) têm complicado o tratamento das infecções nosocomiais, uma vez que sua produção não éfacilmente identificada nos testes de sensibilidade realizados rotineiramente em laboratórios clinicos, levando a dificuldades no controle bospitalar de microrganismos resistentes, bem como ao uso indevido de antibióticos. Objetivo: O objetivo deste trabalho foi analisar o perfil de resistência e a frequência de ESBL em bactérias Gram negativas isoladas de bemoculturas. Foram analisadas 100 amostras bacterianas, provenientes de bemoculturas depacientes adultos, as quais foram identificadas fenotipicamente por provas bioquimicas de fermentação dos carboidratos e submetidas à determinação do perfil de resistência por meio do teste disco difusão e da pesquisa de ESBL, pelos métodos de aproximação de disco e substituição de disco. Resultados: Entre as amostras bacterianas analisadas, 30 foram identificadas como bactérias Gram negativas, com predominio de Proteus mirabilis, Pantoea agglomerans e Escherichia coli. Destas, 73,33\% foram positivas para a pesquisa de ESBL pelos testes fenotípicos aplicados, sendo detectada, principalmente, em Pantoea agglomerans, Proteus mirabilis e Enterobacter cloacae. Conclusão: O aumento da ocorrência de ESBL em diversas enterobactérias revela a importância da ampliação desta detecção em espécies não Escherichia coli e não Klebsiella sp., de modo que as condutas de assistência ao paciente não sejam ameaçadas, já que essas bactérias resistentes podem não ser detectadas pelos laboratórios. Considerando a frequência de ESBL deste estudo, ressalta-se a importância de sua deteç̧ão, tendo em vista sua contribuição na possibilidade de melhorias das políticas de terapia em hospitais.

Unitermos: resistência bacteriana; betalactamase de espectro estendido; ESBL; infecção hospitalar.

\section{REFERENCES}

1. ALVES, L. N. S. et al. Hemoculturas: estudo da prevalência dos microorganismos e o perfil de sensibilidade dos antibióticos utilizados em Unidade de Terapia Intensiva. J Health Sci Inst, v. 30, n. 1, p. 44-7, 2012.

2. CABRAL, A. B. Caracterização genética de isolados clínicos de Klebsiella pneumoniae resistentes a antibióticos $\beta$-lactâmicos de última geração provenientes de Recife-PE. 2011. Dissertação (Programa de Pós-Graduação em Medicina Tropical) - Centro de Ciências da Saúde, Universidade Federal de Pernambuco, Recife. 2011.

3. CLINICAL AND LABORATORY STANDARDS INSTITUTE. Performance standards for antimicrobial susceptibility testing; twenty-second informational supplement. M100-S24, v. 34, n. 1, january 2014.

4. DANTAS, R. C. C. Bacteremia hospitalar por bacilos Gram-negativos multiresistentes: fatores de risco e detecção de ESBL, AmpC e metalo- $\beta$ lactamase. 2011. Dissertação (Mestrado em Imunologia e Parasitologia Aplicadas) - Instituto de Ciências Biomédicas, Universidade Federal de Uberlândia, Uberlândia. 2011.

5. DATTA, P. et al. Epidemiology of extended-spectrum $\beta$-lactamase, AmpC, and carbapenemase production in Proteus mirabilis. Jap J Infect Dis, v. 67, p. 44-6, 2014.

6. JORGENSEN, J. H. et al. Detection of CTX-M-Type extended-spectrum beta-lactamase (ESBLs) by testing with microscan overnight and ESBL confirmation panels. J Clin Microbiol, v. 48, n. 1, p. 120-3, 2010.

7. JUNG, C. L.; MICHELON, C. M. Detecção da produção de betalactamase de espectro estendido em cepas uropatogênicas de Escherichia coli isoladas de pacientes de um laboratório privado da cidade de CriciúmaSC. 2012. Trabalho de conclusão de curso de graduação em Farmácia Universidade do Extremo Sul Catarinense, Criciúma. 2012.
8. KAROLINE, B. R.; BRUST, F. R.; PICOLI, S.U. Disco-aproximação e E-test na pesquisa de enterobactérias produtoras de beta-lactamase de espectro estendido (ESBL). RBAC, v. 40, n. 4, p. 305-8, 2008.

9. KING-TING, L. et al. Characterization of multidrug resistant ESBL producing Escherichia coli isolates from hospitals in Malaysia.J Biomed Biotech, v. 2009, 2009.

10. LAGO, A.; FUENTEFRIA, S. R.; FUENTEFRIA, D. D. Enterobactérias produtoras de ESBL em Passo Fundo, Estado do Rio Grande do Sul, Brasil. Rev Soc Bras Med Trop, v. 43, n. 4, p. 430-4, 2010.

11. LIMA, S. B.; FERREIRA, H. N. Disseminação de Enterobacteriaceae produtoras de beta-lactamase de espectro alargado em crianças. Rev Ped Cent Hosp Port, v. 22, n. 2, p. 87-91, 2013.

12. MARTINS, A. C.; PICOLI, S. U. Métodos alternativos para detecção de betalactamase de espectro estendido em Escherichia coli e Klebsiella pneumoniae.J Bras Patol Med Lab, v. 47, n. 4, p. 421-6, 2011.

13. MENEZES, E. A. et al. Frequência de cepas produtoras de enzima betalactamase de espectro estendido (ESBL) e perfil de susceptibilidade de Klebsiella pneumoniae em hemoculturas no berçário de um hospital de Fortaleza. RBAC, v. 40, n. 1, p. 7-11, 2008.

14. MEYER, G.; PICOLI, S. U. Fenótipos de betalactamases em Klebsiella pneumoniae de Hospital de Emergência de Porto Alegre. J Bras Patol Med Lab, v. 47, n. 1, p. 25-31, 2011.

15. MOREIRA, A. P. A. Infecções hospitalares por Enterobacteriaceae produtoras de $\beta$-lactamase de amplo espectro (ESBL): ocorrência e preditores de mortalidade em um hospital universitário mineiro. 2011. Dissertação (Programa de Pós-graduação em Imunologia e Parasitologia Aplicadas) - Instituto de Ciências Biomédicas, Universidade Federal de Uberlândia, Uberlância. 2011.

16. NOGUEIRA, K. S. Prevalência e caracterização molecular de betalactamases de espectro ampliado (ESBL) em enterobactérias isoladas 
no Hospital de Clínicas de Curitiba. 2011. Tese (Doutorado em Ciências Farmacêuticas) - Setor de Ciências da Saúde, Universidade Federal do Paraná, Curitiba. 2011.

17. OLIVEIRA, K. R. P. $\beta$-lactamases na família Enterobacteriaceae: métodos de detecção e prevalência. 2008. Dissertação (Mestrado em Medicina - Ciências Médicas) - Universidade Federal do Rio Grande do Sul, Rio Grande do Sul. 2008.

18. OLIVEIRA, K. R. P. Prevalência das famílias TEM, SHV e CTX-M de $\beta$-lactamases de espectro estendido em Escherichia coli e Klebsiella spp. no Hospital Universitário de Santa Maria, Estado do Rio Grande do Sul. Rev Soc Bras Med Trop, v. 42, n. 5, p. 556-60, 2009.
19. SEREFHANOGLU, K. et al. Bloodstream infections caused by ESBL - producing E. coli and $K$. pneumoniae: risk factors for multidrugresistance. Braz J Infect Dis, v. 13, n. 6, p. 403-7, 2009.

20. SOARES, S. F. Epidemiologia de estirpes produtores de ESBL em ITU. 2013. Dissertação (Mestrado em Bioquímica) - Departamento de Química, Universidade de Aveiro, Aveiro. 2013.

21. SOUZA, A. S.; TORRES, J. B.; OLIVEIRA, R. C. Identificação laboratorial de $\beta$-lactamases de espectro estendido (ESBLs) em espécimes clínicos de origem hospitalar. $R B A C$, v. 42, n. 4, p. 303-6, 2010.

22. WIEGAND, I. et al. Detection of extended-spectrum beta-lactamase among Enterobacteriaceae by use of semiautomated microbiology systems and manual detection procedures. J Clin Micro, v. 45, p. 1167-74, 2007. 